Reviu Akuntansi dan Bisnis Indonesia, Vol. 3 No. 2, Hlm: 220-238, Desember 2019

Website: http://journal.umy.ac.id/index.php/rab

\title{
Pengaruh Pertumbuhan Ekonomi, Pendapatan Asli Daerah, Dana Alokasi Umum, Dana Alokasi Khusus, dan Dana Bagi Hasil Terhadap Belanja Modal (Studi pada Pemerintah Kabupaten \& Pemerintah Kota di Provinsi Aceh)
}

\author{
Waskito $^{1 *}$; Zuhrotun'; Rusherlisyani ${ }^{2}$ \\ 'Program Studi Akuntansi Universitas Pembangunan Nasional "Veteran" Yogyakarta \\ ${ }^{2}$ Program Studi Akuntansi Universitas Muhammadiyah Yogyakarta
}

I N F O A R T I K E L

\section{Kata Kunci:}

Belanja Modal,

Pertumbuhan Ekonomi,

Pendapatan Asli Daerah,

Dana Alokasi Umum,

Dana Alokasi Khusus,

Dana Bagi Hasil.

Jenis Artikel:

Penelitian Empiris

Correspondence:

waskito3131@gmail.com

\author{
A B S T R A K
}

Latar belakang masalah pada penelitian ini adalah Pemerintah Kabupaten \& Kota di Provinsi Aceh dalam pengelolaan keuangannya masih belum sesuai dengan instruksi Presiden yang tertuang dalam Perpres No.2 tahun 2015 tentang Rencana Pembangunan Jangka Menengah Nasional (RPJMN) dimana target presentase belanja modal yang dialokasikan dalam APBD sekurang-kurangnya 30\% dari total belanja. Penelitian ini bertujuan untuk mengetahui: Pengaruh Pertumbuhan Ekonomi, Pendapatan Asli Daerah, Dana Alokasi Umum, Dana Alokasi Khusus, dan Dana Bagi Hasil terhadap Belanja Modal. Penelitian ini menggunakan metode penelitian kuantitatif. Hasil penelitian menunjukkan bahwa: Pertumbuhan Ekonomi tidak berpengaruh terhadap belanja modal, pendapatan asli daerah tidak berpengaruh terhadap belanja modal, dana alokasi umum berpengaruh terhadap belanja modal, dana alokasi khusus berpengaruh terhadap belanja modal, dan dana bagi hasil tidak berpengaruh terhadap belanja modal. Keterbatasan pada penelitian ini Penelitian ini hanya berdasarkan pada data kuantitatif yaitu Laporan Realisasi Anggaran pada Laporan Keuangan Pemerintah Daerah Aceh tahun 2015 - 2017, tidak mengkaji lebih mendalam terkait aspek kualitatif seperti kebijakan pemerintah dalam penyusunan anggaran Belanja Modal dikarenakan informasi tersebut tidak termasuk informasi yang harus dipublikasikan ke publik. Peneliti menyatakan bahwa penelitian dengan judul diatas adalah benar-benar asli karya tulis saya dan sepanjang pengetahuan saya tidak terdapat karya ilmiah yang pernah diajukan oleh orang lain untuk memeroleh gelar akademik di perguruan tinggi, dan tidak terdapat karya yang pernah di tulis atau diterbitkan orang lain, kecuali yang secara tertulis dikutip dalam penelitian ini dan disebutkan dalam daftar pustaka, apabila dikemudian hari dapat dibuktikan terdapat unsur-unsur plagiasi maka saya bersedia diproses sesuai dengan peraturan perundang-undangan yang berlaku.

(C) 2019 RAB. Published by Universitas Muhammadiyah Yogyakarta

\section{PENDAHULUAN}

Sejak diberlakukannya sistem desentralisasi di Indonesia, Pemerintah Daerah memiliki kewenangan untuk mengatur urusan pemerintahan di daerahnya sendiri. Kewenangan daerah yang 
diterima dari Pemerintah Pusat diatur dalam UU No. 9 tahun 2015 tentang Pemerintah Daerah. Salah satu kewenangan yang dimiliki adalah Pemerintah Daerah mempunyai wewenang untuk menggunakan sumber-sumber pendapatan yang menjadi hak Pemerintah Daerah untuk dimanfaatkan atau dikelola untuk program kerja atau belanja yang dapat bersinggungan langsung dengan masyarakat seperti pembangunan atau pemeliharaan infrastruktur yang nantinya akan berkaitan dengan peningkatan pelayanan publik. Tujuan utama desentralisasi adalah mewujudkan kesejahteraan melalui penyediaan pelayanan publik yang lebih merata diseluruh daerah di Indonesia serta memperpendek jarak antara penyedia layanan publik dan masyarakat lokal (Kusnandar dan Dodik, 2012). Oleh karena itu salah satu kunci yang harus diperhatikan dalam desentralisasi adalah Pemerintah Daerah harus lebih responsif terhadap kebutuhan penduduknya sehingga berdampak pada peningkatan kesejahteraan masyarakat yang pada akhirnya dapat mengurangi kemiskinan di daerah (Jolianis, 2016).

Belanja modal adalah pengeluaran anggaran untuk perolehan aset tetap dan aset lainnya yang memberikan manfaat lebih dari satu periode akuntansi, termasuk di dalamnya adalah pengeluaran untuk biaya pemeliharaan yang sifatnya mempertahankan atau menambah masa manfaat, serta meningkatkan kapasitas dan kualitas aset. Belanja modal meliputi belanja untuk perolehan tanah, gedung dan bangunan, peralatan, dan aset tak berwujud (PP/71/2010). Belanja modal berkaitan dengan Rencana Pembangunan Jangka Menengah Nasional (RPJMN) Tahun 2015-2019, salah satu dari 9 agenda pembangunan nasional adalah membangun Indonesia dari pinggiran dengan memperkuat daerah-daerah dan desa untuk mendukung peningkatan pertumbuhan ekonomi. Agenda tersebut sesuai dengan tujuan desentralisasi yaitu pemerataan pembangunan antar daerah di Indonesia untuk mengurangi ketimpangan yang terjadi antar daerah yang berkaitan dengan sarana dan prasarana, pendapatan, serta kualitas SDM yang dimiliki. Untuk mendukung agenda tersebut sesuai instruksi Presiden yang tercantum pada RPJMN Tahun 2015-2019, Pemerintah Daerah dituntut untuk mengalokasikan pendapatan yang dimilikinya untuk belanja daerah yang bersifat produktif seperti belanja modal. Hal tersebut direalisasikan oleh pemerintah pusat dengan memberikan batas minimal untuk belanja modal sebesar $30 \%$ dari total belanja daerah yang dialokasikan pada APBD tiap daerah setiap tahunnya.

Tabel 1 Data Presentase Belanja Modal Kabupaten/Kota TA. 2015-2017

\begin{tabular}{lllll}
\hline No & Nama Daerah & \multicolumn{2}{l}{ Presentase Belanja Modal } \\
\cline { 3 - 4 } & & 2015 & 2016 & 2017 \\
\hline 1 & Kab. Aceh Barat & 24 & 22 & 23 \\
2 & Kab. Aceh Besar & 18 & 22 & 23 \\
3 & Kab. Aceh Selatan & 30 & 29 & 30 \\
4 & Kab. Aceh Singkil & 41 & 36 & 26 \\
5 & Kab. Aceh Tengah & 29 & 37 & 34 \\
6 & Kab. Aceh Tenggara & 28 & 35 & 33 \\
7 & Kab. Aceh Timur & 26 & 27 & 27 \\
8 & Kab. Aceh Utara & 22 & 20 & 22 \\
9 & Kab. Bireuen & 22 & 24 & 27 \\
10 & Kab. Pidie & 22 & 25 & 21 \\
11 & Kab. Simeulue & 24 & 31 & 30 \\
12 & Kota Banda Aceh & 19 & 32 & 21 \\
13 & Kota Sabang & 24 & 29 & 36 \\
14 & Kota Langsa & 23 & 41 & 26 \\
15 & Kota Lhokseumawe & 27 & 39 & 29 \\
16 & Kab. Gayo Lues & 38 & 39 & 31 \\
17 & Kab. Aceh Barat Daya & 31 & 34 & 33 \\
18 & Kab. Aceh Jaya & 33 & 32 & 37 \\
19 & Kab. Nagan Raya & 40 & 28 \\
20 & Kab. Aceh Tamiang & 34 & & \\
\hline
\end{tabular}

Sumber: Laporan Hasil Pemeriksaan BPK RI 
Pemerintah Provinsi Aceh dalam pengelolaan keuangannya masih belum sesuai dengan instruksi Presiden yang tertuang dalam Perpres No.2 tahun 2015 tentang Rencana Jangka Menengah Nasional (RPJMN) dimana target presentase belanja modal yang dialokasikan dalam APBD sekurang-kurangnya 30\% dari total belanja. Sementara presentase Belanja Modal pada Kabupaten/ Kota di Provinsi Aceh dari tahun 2015-2017 mengalami fluktuasi. Dapat dilihat pada tabel dibawah bahwa pada tahun 2015 terdapat 14 (empat belas) kabupaten/ kota yang belum memenuih himbauan yaitu: Aceh Barat, Aceh Besar, Aceh Tengah, Aceh Tenggara, Aceh Timur, Aceh Utara, Bireuen, Pidie, Simeulue, Banda Aceh, Sabang, Langsa, Lhokseumawe, Bener Meriah, bahkan ada Kabupaten Aceh Besar presentasenya sangat kecil yaitu $18 \%$. Pada tahun 2016 jumlah kabupaten/kota yang belum memenuih himbauan diatas berkurang, terdapat 10 (sepuluh) kabupaten/ kota yang belum memenuih himbauan yaitu: Aceh Barat, Aceh Besar, Aceh Selatan, Aceh Timur, Aceh Utara, Bireuen, Pidie, Simeulue, Banda Aceh, Lhokseumawe. Sedangkan pada tahun 2017 ada 12 (dua belas) kabupaten/ kota yang belum memenuih himbauan tersebut yaitu Aceh Barat, Aceh Besar, Aceh Singkil, Aceh Timur, Aceh Utara, Bireuen, Pidie, Banda Aceh, Sabang, Lhokseumawe, Gayo Lues.

Dari data diatas dapat diketahui bahwa setiap kabupaten/ kota memiliki laju Belanja Modal yang selalu naik dan turun setiap tahunnya. Semakin tinggi prosentase belanja modal suatu daerah mencerminkan semakin makmur dan semakin baik daerah tersebut. Kabupaten/Kota dengan prosentase Belanja modal tinggi mengartikan bahwa daerah tersebut mempunyai dana cukup dan sudah memenuih himbauan pemerintah pusat dengan mengalokasikan belanja modal lebih dari batas minimal dan belanja tersebut dapat berdampak pada penyediaan pelayanan yang lebih baik. Tersedianya pelayanan publik yang baik akan berdampak pada lancarnya kegiatan perekonomian setempat karena akan menarik investor yang akan berinvestasi di daerah tersebut. Sebaliknya, kabupaten/kota dengan presentase belanja modal yang rendah mencerminkan daerah tersebut tidak memiliki dana yang cukup untuk mengalokasikan belanja modal dikarenakan adanya pelaksanaan proritas anggaran untuk hal lain. Akan tetapi hal tersebut akan berdampak terhadap pelayanan publik kepada masyarakat karena jika infrastruktur atau aset tetap yang dimiliki kurang memadai maka akan berdampak terhadap produktifitas masyarakat dan dapat mengurangi daya tarik bagi investor untuk menanamkan modalnya didaerah tersebut bahkan akan menganggu pertumbuhan ekonomi didaerah tersebut.

Dalam anggaran pemerintah daerah, porsi belanja modal dalam APBD merupakan komponen belanja yang sangat penting karena realisasi atas belanja modal yang dilaksanakan oleh pemerintah daerah akan memiliki multiplier effect untuk menggerakan rasio pertumbuhan ekonomi dalam struktur APBD, diharapkan akan semakin baik pengaruhnya terhadap pertumbuhan ekonomi. Sebaliknya, semakin rendah angkanya, semakin berkurang pengaruhnya terhadap pertumbuhan ekonomi ( Sugiyanta, 2016).

Pertumbuhan Ekonomi yang tinggi mendorong pemerintah daerah untuk melakukan pembangunan daerah yang mandiri melalui Belanja Modal yang direalisasikan dalam bentuk pengadaan fasilitas, infrastruktur dan sarana prasarana yang ditujukan untuk kepentingan publik. Untuk mewujudkan pembangunan daerah yang mandiri ini maka pemerintah daerah diberikan kewenangan untuk memanfaatkan sumber-sumber keuangan yang bersumber dari daerah itu sendiri yaitu Pendapatan Asli Daerah (PAD).

Pendapatan asli daerah merupakan sumber penerimaan Pemerintah Daerah yang berasal dari pengelolaan potensi didaerahnya sendiri. Dalam Undang-undang Nomor 9 tahun 2015 mengatakan bahwa Pendapatan Asli Daerah adalah semua hak daerah yang diakui sebagai penambah nilai kekayaan bersih dalam periode tahun anggaran yang bersangkutan, terdiri dari hasil pungutan pajak daerah, retribusi daerah,hasil perusahaan milik daerah dan hasil pengelolaan kekayaan daerah yang dipisahkan, dan lain-lain pendapatan asli daerah yang sah. Menurut Mardiasmo (2002) saat ini masih banyak masalah yang dihadapi pemerintah daerah terkait dengan upaya meningkatkan penerimaan daerah akan tetapi pemerintah daerah memiliki sarana dan prasarana yang tidak mendukung untuk investasi menimbulkan pertanyaan bagaimana sebenarnya peran PAD terhadap Belanja Modal, apakah karena PAD yang rendah atau alokasi yang kurang tepat. Namun tidak semua daerah memiliki pendapatan asli daerah yang besar untuk memenuih 
kebutuhan daerahnya dikarenakan setiap daerah memiliki potensi yang berbeda-beda. Dampak dari perbedaan ini adalah terjadinya ketimpangan sumber pendanaan antar daerah dimana daerah yang kaya akan potensi dan sumber daya memiliki sumber pendanaan yang lebih besar dibanding daerah yang miskin akan potensi daerahnya.

Dana Alokasi Umum adalah dana yang bersumber dari pendapatan APBN yang dialokasikan dengan tujuan pemerataan kemampuan keuangan antar-Daerah untuk mendanai kebutuhan Daerah dalam rangka pelaksanaan Desentralisasi. Adanya transfer dana dari pusat ini diharapkan pemerintah daerah bisa lebih mengalokasikan PAD yang didapatnya untuk membiayai belanja modal di daerahnya.

Dana Alokasi Khusus yaitu dana yang bersumber dari pendapatan APBN yang dialokasikan kepada daerah tertentu dengan tujuan untuk membantu mendanai kegiatan khusus yang merupakan urusan daerah dan sesuai dengan prioritas nasional (UU/9/2015). DAK ini penggunaannya diatur oleh Pemerintah Pusat dan digunakan untuk kegiatan pendidikan, kesehatan, keluarga berencana, infrastruktur jalan dan jembatan, infrastruktur irigasi, infrastruktur air minum dan sanitasi, prasarana pemerintah daerah, lingkungan hidup, kehutanan, sarana prasarana pedesaan, perdagangan, pertanian serta perikanan dan kelautan yang semuanya itu termasuk dalam komponen belanja modal dan Pemerintah Daerah diwajibkan untuk mengalokasikan dana pendamping sebesar $10 \%$ dari nilai DAK yang diterimanya untuk mendanai kegiatan fisik (Wandira, 2013).

Dana Bagi Hasil adalah dana yang bersumber dari pendapatan APBN yang dialokasikan kepada Daerah berdasarkan angka persentase untuk mendanai kebutuhan Daerah dalam rangka pelaksanaan Desentralisasi. DBH yang ditransfer pemerintah pusat kepada pemerintah daerah terdiri dari 2 jenis, yaitu DBH pajak dan DBH bukan pajak (Sumber Daya Alam). DBH merupakan sumber pendapatan daerah yang cukup potensial dan merupakan salah satu modal dasar pemerintah daerah dalam mendapatkan dana pembangunan dan memenuhi belanja daerah yang bukan berasal dari PAD selain DAU dan DAK.

Penelitian ini penting agar dapat mengetahui pengaruh pertumbuhan ekonomi, pendapatan asli daerah, dana alokasi umum, dana alokasi khusus, dan dana bagi hasil terhadap belanja modal. Penelitian ini merupakan pengembangan dari penelitian Aditya dan Maryono (2018). Pada penelitian ini, peneliti termotivasi meneliti kembali tentang Pengaruh Pendapatan Asli Daerah, Dana Alokasi Umum, Dana Alokasi Khusus, Dan Dana Bagi Hasil Terhadap Belanja Modal. Hal ini disebabkan masih adanya kontradiksi hasil penelitian terdahulu. Selain itu, peneliti juga menambahkan satu variabel yaitu Pertumbuhan Ekonomi. Penambahan variabel tersebut disebabkan adanya kontradiksi dari hasil penelitian terdahulu. Hal lain yang menyebabkan peneliti tertarik untuk menambahkan variabel tersebut dikarenakan adanya tren positif terhadap pertumbuhan ekonomi di Provinsi Aceh. Pertumbuhan Ekonomi Provinsi Aceh menunjukan adanya peningkatan akan tetapi realisasi belanja modal pada kabupaten/kota Provinsi Aceh cenderung fluktuatif. Seharusnya pertumbuhan ekonomi yang selalu mengalami kenaikan itu berdampak terhadap belanja modal, dikarenakan pertumbuhan ekonomi naik tercipta dari infrastruktur atau sarana dan prasarana yang memadai dampak dari aset yang dihasilkan dari realisasi belanja modal sehingga dapat meningkatkan pertumbuhan ekonomi. Akan tetapi peningkatan pertumbuhan ekonomi pada Kabupaten/Kota pada Provinsi Aceh peningkatan tersebut tidak berdampak kepada realisasi belanja modal.

\section{TINJAUAN LITERATUR DAN PERUMUSAN HIPOTESIS}

Teori Agensi

MenurutJensen dan Meckling (1976) dalam teori agensi terdapat dua pihak yakni pihak yang memberikan wewenang yang disebut prinsipal dan pihak yang menerima kewenangan yang disebut agen. Hubungan prinsipal-agen terjadi apabila tindakan yang dilakukan seseorang memiliki dampak pada orang lain atau ketika seseorang sangat tergantung pada tindakan orang lain. Pengaruh atau 
ketergantungan ini diwujudkan dalam kesepakatan-kesepakatan dalam struktur institusional pada berbagai tingkatan, seperti norma perilaku dan konsep kontrak. Teori agensi lebih sering dibahas dalam konteks manajemen perusahaan yang berorientasi bisnis. Menurut Lane (2003a), Teori keagenan dapat diterapkan dalam organisasi sektor publik. Dalam organisasi sektor publik, khususnya pemerintahan pusat dan daerah di Indonesia telah mempraktikan teori agensi. Hal ini dibuktikan dengan diberlakukannya kebijakan desentralisasi yang dituangkan dalam UU No 9 Tahun 2015 tentang Pemerintah Daerah. UU tersebut memisahkan dengan tegas antara pemerintah daerah (eksekutif) dengan fungsi perwalian rakyat (legislatif). Berdasarkan pembedaan fungsi tersebut, eksekutif melakukan perencanaan, pelaksanaan, dan pelaporan atas anggaran daerah, yang merupakan manifestasi dari pelayanan kepada publik, sedangkan legislatif berperan aktif dalam melaksanakan legislasi, penganggaran, dan pengawasan. Teori ini menjelaskan kepentingan antara pihak manajerial dengan pemilik yang kepentingannya tidak sama, sehingga dapat terjadi konflik. Konflik tersebut dinamakan konflik keagenan. Dalam teori ini dapat membagi secara rata atau menyelaraskan antara hak masing-masing pihak antara pihak agen dan pihak prinsipal beserta kewajibannya dan kepentingan masing-masing pihak tersebut. Inti dari teori agensi adalah untuk memadukan antara kepentingan prinsipal dan agen agar tidak terjadi konflik kepentingan.

\section{Hubungan Keagenan Antara Eksekutif dan Legislatif}

Dalam hubungan keagenan antara eksekutif dan legislatif, eksekutif adalah agen dan legislatif adalah prinsipal (Abdullah dan Halim, 2006). Seperti dikemukakan sebelumnya, diantaranya prinsipal dan agen senantiasa terjadi masalah keagenan. Oleh karena itu, persoalan yang timbul diantara eksekutif dan legislatif juga merupakan persoalan keagenan.

\section{Anggaran Pendapatan dan Belanja Daerah}

Anggaran Pendapatan dan Belanja Daerah menurut Undang-undang Nomor 9 Tahun 2015 adalah suatu susunan/rencana keuangan tahunan Daerah yang ditetapkan dengan Peraturan Daerah. Anggaran daerah merupakan salah satu peran sangat penting dalam meningkatkan pelayanan publik yang didalamnya tercermin kebutuhan masyarakat sesuai dengan potensi dan sumber-sumber kekayaan daerah. Mengingat peran APBD yang sangat penting karena APBD merupakan sebuah alat untuk pendorong atau penentu tercapainya target dan sarana makro ekonomi daerah untuk mengatasi permasalahan-permasalahan dan kenadala-kendala yang terjadi di masyarakat yang merupakan suatu tantangan untuk mewujudkan kesejahteraan masyarakat. Kebijakan pengelolaan APBD difokuskan pada optimalisasi fungsi dan manfaat pendapatan, belanja dan pembiayaan bagi tercapainya sasaran atas agenda pembangunan tahunan.

\section{Belanja Modal}

Menurut Peraturan Menteri Keuangan Republik Indonesia No.214/PMK.05/2013, belanja modal merupakan pengeluaran anggaran dalam rangka memperoleh atau menambah aset tetap dan/atau aset lainnya yang memberi manfaat ekonomis lebih dari satu periode akuntansi 12 (dua belas) bulan) serta melebihi batasan nilai minimum kapitalisasi aset tetap atau aset lainnya yang ditetapkan oleh pemerintah dimana set tersebut dipergunakan untuk operasional kegiatan seharihari suatu satuan kerja dan bukan untuk dijual.

Pertumbuhan Ekonomi

Pertumbuhan ekonomi merupakan angka yang menunjukan kenaikan kegiatan perekonomian suatu daerah setiap tahunnya. Pertumbuhan Ekonomi dapat diciptakan apabila didukung oleh infrastruktur atau sarana prasarana daerah yang baik, infrastruktur atau sarana prasarana tersebut menunjang potensi lokalnya seperti masyarakat untuk semakin berkembang 
sehingga tercipta pertumbuhan ekonomi pada daerah tersebut. Pemerintah Indonesia mempunyai target pertumbuhan ekonomi sebesar $7 \%$ yang harus dicapai selama 2014-2019 yang tercantum pada Rencana Pembangunan Jangka Menengah Nasional. Pemerintah Daerah mempunyai andil untuk membantu pemerintah pusat mencapai target pertumbuhan ekonomi dikarenakan ekonomi nasional dan ekonomi daerah berhubungan secara timbal balik. Hal tersebut yang mendasari pemerintah pusat memberikan instruksi yang juga tercantum dalam RPJMN yaitu pemerintah kabupaten/kota diharuskan mengalokasikan belanja modal minimal sebesar $30 \%$ dari total belanja daerah. Instruksi tersebut yang menyebabkan alokasi belanja modal akan meningkat dikarenakan pemerintah daerah mempunyai tanggung jawab kepada pemerintah pusat untuk membantu mencapai target pertumbuhan ekonomi dengan cara pengalokasian belanja yang produktif yaitu belanja modal. Hasil penelitian yang dilakukan oleh Purwanto (2013), Sudrajat dan Purniawati (2017), Ayem dan Pratama (2018) menunjukkan bahwa pertumbuhan ekonomi berpengaruh terhadap belanja modal.

\section{Pendapatan Asli Daerah}

Pendapatan Asli Daerah merupakan sumber keuangan yang diperoleh dari hasil pengelolaan sumber daya yang ada di daerah tersebut. Pendapatan Asli Daerah merupakan salah satu sumber pendapatan yang penting bagi daerah untuk memenuih belanjanya khususnya untuk belanja modal. Pendapatan Asli Daerah didapatkan dari hasil pajak daerah, hasil retribusi daerah, hasil pengelolaan kekayaan daerah yang dipisahkan dan lain-lain Pendapatan Asli Daerah yang sah. Bila disesuaikan dengan Teori Agensi (Jensen dan Meckling, 1976), hubungan kontraktual antara agen (masyarakat) dan prinsipal (pemerintah) dalam konteks Pendapatan Asli Daerah dapat dilihat dari kemampuan dan tanggungjawab pemerintah daerah untuk memberikan pelayanan publik yang baik serta meningkatkan kesejahteraan masyarakat melalui belanja modal, yaitu dengan menyediakan sarana dan prasarana yang memadai yang dibiayai dari belanja modal, sedangkan belanja modal itu sendiri salah satu sumber pembiayaannya dari Pendapatan Asli Daerah. Pemerintah daerah (agen) bertanggungjawab kepada masyarakat (principle) karena masyarakat telah memberikan sebagian uangnya kepada pemerintah melalui pajak, retribusi, dan lain-lain. Hasil penelitian yang dilakukan oleh Khasanah (2016), Nopitasari (2017), Aditya dan Dirgantari (2017) menunjukkan bahwa pendapatan asli daerah berpengaruh terhadap belanja modal.

Dana Alokasi Umum

Dana Alokasi Umum adalah merupakan transfer yang bersifat umum (block grant) yang diberikan kepada semua kabupaten dan kota untuk tujuan mengisi kesenjangan antara kapasitas dan kebutuhan fiskalnya dan didistribusikan dengan formula berdasarkan prinsip-prinsip tertentu yang secara umum mengindikasikan bahwa daerah miskin dan terbelakang harus menerima lebih banyak dari pada daerah kaya (Fadillah, 2017). Dengan adanya transfer DAU dari pemerintahan pusat, maka daerah bisa lebih fokus untuk menggunakan PAD yang dimilikinya untuk membiayai Belanja Modal yang menunjang tujuan pemerintahan yaitu meningkatkan pelayanan publik. Transfer DAU dari pemerintah pusat dapat menunjuang pemerintah daerah untuk meningkatkan pelayanan publik melalui pembangunan infrastruktur serta sarana melalui alokasi anggaran Belanja Modal, dengan meningkatnya pelayanan publik diharapkan pula menunjang peningkatan pendapatan masyarakat. Hasil penelitian yang dilakukan oleh Yawa dan Runtu (2015), Mubasiroh (2018), Sulistyorini (2018) menunjukkan bahwa dana alokasi umum berpengaruh terhadap belanja modal.

\section{Dana Alokasi Khusus}

Dana Alokasi Khusus merupakan dana perimbangan yang diberikan kepada pemerintah daerah untuk membiayai khusus yang merupakan urusan daerah dan prioritas pembangunan nasional. Tujuannya untuk mengurangi beban biaya kegiatan khusus yang harus ditanggung oleh 
pemerintah daerah (Ardhini, 2011). Pemanfaatan DAK diarahkan kepada kegiatan investasi pembangunan, pengadaan, peningkatan perbaikan sarana dan prasarana fisik pelayanan publik dengan umur ekonomis panjang. Dengan diarahkannya pemanfaatan DAK untuk kegiatan tersebut diharapkan dapat meningkatkan pelayanan publik dengan cara meningkatkan belanja modal. Selain itu, ada yang berpendapat bahwa DAK merupakan salah satu sumber pendanaan untuk sebuah Belanja Modal (Pohan, 2018). Hal ini mengindikasikan bahwa terdapat hubungan antara pemberian dana transfer dari pemerintah pusat (DAK) dengan alokasi anggaran pengeluaran daerah melalui Belanja Modal. Hasil penelitian yang dilakukan oleh Karyadi (2017), Fadillah (2017), Gerungan dkk (2017) menunjukkan bahwa dana alokasi khusus berpengaruh terhadap belanja modal.

\section{Dana Bagi Hasil}

Berdasarkan UU No. 33 tahun 2004 tentang Dana Perimbangan, dana bagi hasil merupakan dana yang bersumber dari pajak dan sumber daya alam. Dana yang bersumber dari pajak terdiri atas pajak bumi dan bangunan (PBB), bea perolehan atas tanah dan bangunan (BPHTB) dan pajak penghasilan $(\mathrm{PPh})$, sedangkan dana yang bersumber dari sumber daya alam meliputi kehutanan, mineral dan batu bara, minyak bumi dan gas bumi, pengusahaan panas bumi dan perikanan. Tujuan Dana Bagi Hasil adalah untuk memperbaiki keseimbangan vertikal antara pusat dan daerah dengan memperhatikan potensi daerah penghasil. Dana Bagi Hasil merupakan sumber pendapatan daerah yang potensial dan merupakan salah satu modal dasar pemerintah daerah dalam mendapatkan dana pembangunan dan memenuih belanja daerah yang bukan berasal dari Pendapatan Asli Daerah selain Dana Alokasi Umum dan Dana Alokasi Khusus. Pendapatan daerah yang berupa Dana Bagi Hasil tentu harus digunakan oleh pemerintah daerah untuk membangun dan mensejahterakan masyarakat melalui pengelolaan kekayaan daerah yang proposional dan profesional serta membangun infrastruktur yang berkelanjutan, salah satunya digunakan untuk belanja modal. Maka semakin besar Dana Bagi Hasil yang didapat suatu daerah maka daerah tersebut cenderung memiliki belanja modal yang besar pula dikarenakan pemerintah daerah mendapatkan tambahan pendapatan yang didapat dari dana perimbangan tersebut. Hasil penelitian yang dilakukan oleh Junaedy (2015), Susanti dan Fahlevi (2016), Susanti (2016) menunjukkan bahwa dana bagi hasil berpengaruh terhadap belanja modal.

\section{Pengaruh Pertumbuhan Ekonomi terhadap Belanja Modal}

Kebijakan otonomi daerah merupakan kewenangan yang diberikan kepada pemerintah daerah untuk mengatur urusan pemerintahannya sendiri dengan sedikit bantuan dari pemerintah pusat. Berdasarkan UU No. 9 Tahun 2015 tentang Pemerintah Daerah, Pemerintah Daerah ditugaskan untuk mempercepat terwujudnya kesejahteraan masyarakat melalui penipngkatan pelayanan publik, fasilitas umum, pemberdayaan, dan peran serta masyarakat dalam rangka desentralisasi, akan tetapi masing-masing pemerintah daerah memiliki kemampuan yang berbeda satu sama lain dalam mengelola potensi lokalnya dan ketersediaan sarana prasarana serta sumber daya yang sangat berbeda. Perbedaan ini dapat menyebabkan Pertumbuhan Ekonomi yang beragam antara satu daerah dengan daerah lainnya. Pertumbuhan ekonomi merupakan salah satu indikator yang penting untuk mengetahui hasil usaha/kerja pemerintah daerah dalam memajukan daerahnya. Pertumbuhan Ekonomi dapat diciptakan apabila didukung oleh infrastruktur atau sarana prasarana daerah yang baik, infrastruktur atau sarana prasarana tersebut menunjang potensi lokalnya seperti masyarakat untuk semakin berkembang sehingga tercipta Pertumbuhan Ekonomi pada daerah tersebut.

Berdasarkan penelitian yang dilakukan oleh Purwanto (2013), memperoleh hasil bahwa pertumbuhan ekonomi berpengaruh positif terhadap variabel belanja modal. Penelitian yang dilakukan oleh Ayem dan Pratama (2018), memperoleh hasil berupa terdapat pengaruh positif antara pertumbuhan ekonomi dengan belanja modal. Sedangkan penelitian yang dilakukan oleh 
Sudrajat dan Purniawati (2017), memperoleh hasil berupa terdapat pengaruh negatif antara pertumbuhan ekonomi dengan belanja modal.

\section{$\boldsymbol{H}_{\boldsymbol{I}} \quad$ : Pertumbuhan Ekonomi berpengaruh terhadap belanja modal.}

Pengaruh Pendapatan Asli Daerah terhadap Belanja Modal

Pendapatan Asli Daerah merupakan sumber keuangan yang diperoleh dari hasil pengelolaan sumber daya yang ada di daerah tersebut. Pendapatan Asli Daerah merupakan salah satu sumber pendapatan yang penting bagi daerah untuk memenuih belanjanya khususnya untuk belanja modal. Pendapatan Asli Daerah didapatkan dari hasil pajak daerah, hasil retribusi daerah, hasil pengelolaan kekayaan daerah yang dipisahkan dan lain-lain Pendapatan Asli Daerah yang sah. PP No.12 tahun 2019 tentang Pengelolaan Keuangan Daerah yang menyatakan bahwa APBD disusun sesuai dengan penyelenggaraan pemerintahan dan kemampuan daerah, yang diartikan bahwa Pemerintah Daerah akan mengalokasikan belanja modal maka harus disesuaikan dengan kebutuhan daerah dengan pertimbangan Pendapatan Asli Daerah yang diterima.

Berdasarkan penelitian yang dilakukan oleh Nopitasari (2017), hasil penelitian tersebut menunjukan adanya pengaruh positif antara pendapatan asli daerah dengan variabel belanja modal. Penelitian serupa yang dilakukan oleh Aditya dan Dirgantari (2017), memperoleh hasil bahwa pendapatan asli daerah berpengaruh terhadap variabel belanja modal. Sedangkan penelitian yang dilakukan oleh Khasanah (2016), menyatakan bahwa ada pengaruh positif antara pendapatan asli derah dengan belanja modal.

\section{$\boldsymbol{H}_{2} \quad$ : Pendapatan Asli Daerah berpengaruh terhadap belanja modal.}

Pengaruh Dana Alokasi Umum terhadap Belanja Modal

Dalam rangka pemberian dukungan terhadap pelaksanaan otonomi daerah telah diterbitkan Undang-Undang No.33 Tahun 2004 tentang Perimbangan Keuangan yang diberikan kepada Pemerintah Daerah guna mengatasi ketimpangan yang terjadi dikarenakan setiap daerah memiliki sumber daya yang berbeda-beda atas dasar keadlilan pemerintah pusat memberikan dana perimbangan kepada pemerintah daerah untuk mendukung pelaksanaan desentralisasi. Berkaitan dengan dana perimbangan keuangan antara pemerintah pusat dan daerah, hal tersebut merupakan konsekuensi adanya penyerahan kewenangan pemerintahan pusat kepada pemerintah daerah. Untuk mendukung terhadap pelaksanaan otonomi daerah, terjadi transfer yang cukup signifikan didalam APBN dari pemerintah pusat ke pemerintah daerah, dan pemerintah daerah diberi keleluasan untuk mengelola dana tersebut untuk memberi pelayanan yang lebih baik kepada masyarakat. Pemerintah Pusat mengharapkan dengan adanya desentralisasi fiskal pemerintah daerah lebih mengoptimalkan kemampuannya dalam mengelola sumber daya yang dimiliki sehingga tidak bergantung terhadap dana transfer Dana Alokasi Umum. Dengan adanya transfer DAU dari pemerintahan pusat, maka daerah bisa lebih fokus untuk menggunakan PAD yang dimilikinya untuk membiayai Belanja Modal yang menunjang tujuan pemerintahan yaitu meningkatkan pelayanan publik. Transfer DAU dari pemerintah pusat dapat menunjuang pemerintah daerah untuk meningkatkan pelayanan publik melalui pembangunan infrastruktur serta sarana melalui alokasi anggaran belanja modal, dengan meningkatnya pelayanan publik diharapkan pula menunjang peningkatan pendapatan masyarakat.

Berdasarkan penelitian yang dilakukan oleh Yawa dan Runtu (2015), menunjukan adanya pengaruh positif antara dana alokasi umum dengan variabel belanja modal. Penelitian serupa yang dilakukan oleh Mubasiroh (2018), memperoleh hasil bahwa dana alokasi umum berpengaruh positif terhadap variabel belanja modal. Sedangkan pada penelitian Sulistyorini (2018), menyatakan bahwa terdapat pengaruh positif antara dana alokasi umum dengan belanja modal. 


\section{$\boldsymbol{H}_{3} \quad$ : Dana Alokasi Umum berpengaruh terhadap belanja modal.}

\section{Pengaruh Dana Alokasi Khusus terhadap Belanja Modal}

Dana Alokasi Khusus merupakan dana perimbangan yang diberikan kepada pemerintah daerah untuk membiayai khusus yang merupakan urusan daerah dan prioritas pembangunan nasional. Tujuannya untuk mengurangi beban biaya kegiatan khusus yang harus ditanggung oleh pemerintah daerah (Ardhini, 2011). Pemanfaatan DAK diarahkan kepada kegiatan investasi pembangunan, pengadaan, peningkatan perbaikan sarana dan prasarana fisik pelayanan publik dengan umur ekonomis panjang. Dengan diarahkannya pemanfaatan DAK untuk kegiatan tersebut diharapkan dapat meningkatkan pelayanan publik dengan cara meningkatkan belanja modal. Selain itu, ada yang berpendapat bahwa DAK merupakan salah satu sumber pendanaan untuk sebuah Belanja Modal (Pohan, 2018). Hal ini mengindikasikan bahwa terdapat hubungan antara pemberian dana transfer dari pemerintah pusat (DAK) dengan alokasi anggaran pengeluaran daerah melalui Belanja Modal.

Berdasarkan penelitian yang dilakukan oleh Karyadi (2017), menunjukan adanya hubungan positif antara dana alokasi khusus dengan variabel belanja modal. Penelitian serupa yang dilakukan oleh Fadillah (2017), memperoleh hasil bahwa dana alokasi khusus berpengaruh positif terhadap variabel belanja modal. Sedangkan penelitian yang dilakukan oleh Gerungan dkk (2017), menyatakan bahwa terdapat pengaruh positif antara dana alokasi khusus dengan belanja modal.

\section{$\boldsymbol{H}_{4} \quad$ : Dana Alokasi Khusus berpengaruh terhadap belanja modal.}

\section{Pengaruh Dana Bagi Hasil terhadap Belanja Modal}

Dana Bagi Hasil merupakan salah satu sumber pendapatan yang berasal dari dana perimbangan yang diberikan oleh pemerintah untuk membantu pemerintah daerah untuk menjalankan urusan pemerintahannya salah satunya untuk pelaksanaan program yang langsung bersinggungan dengan masyarakat umum yaitu peningkatan pelayanan umum dengan cara membangun dan memperbaiki sarana prasarana didaerah tersebut. Berdasarkan UU No. 33 tahun 2004 tentang Dana Perimbangan, dana bagi hasil merupakan dana yang bersumber dari pajak dan sumber daya alam. Dana yang bersumber dari pajak terdiri atas pajak bumi dan bangunan (PBB), bea perolehan atas tanah dan bangunan (BPHTB) dan pajak penghasilan (PPh), sedangkan dana yang bersumber dari sumber daya alam meliputi kehutanan, mineral dan batu bara, minyak bumi dan gas bumi, pengusahaan panas bumi dan perikanan. Tujuan Dana Bagi Hasil adalah untuk memperbaiki keseimbangan vertikal antara pusat dan daerah dengan memperhatikan potensi daerah penghasil.

Berdasarkan penelitian yang dilakukan oleh Junaedy (2015), menunjukan adanya hubungan positif antara dana bagi hasil dengan variabel belanja modal. Penelitian serupa yang dilakukan oleh Susanti dan Fahlevi (2016), memperoleh hasil bahwa dana bagi hasil berpengaruh positif terhadap variabel belanja modal. Sedangkan penelitian yang dilakukan oleh Susanti (2016), menyatakan bahwa terdapat pengaruh positif antara dana bagi hasil dengan belanja modal.

\section{$\boldsymbol{H}_{5} \quad$ : Dana Bagi Hasil berpengaruh terhadap belanja modal.}

\section{METODE PENELITIAN}

Metode penelitian yang digunakan dalam penelitian ini adalah metode kuantitatif. Subyek atau populasi yang diteliti adalah seluruh pemerintahan kabupaten/kota yang berada pada Provinsi Aceh yaitu sebanyak 18 Kabupaten dan 5 Kota. Obyek yang diteliti pada penelitian ini adalah data 
variabel Pertumbuhan Ekonomi, Pendapatan Asli Daerah, Dana Alokasi Umum, Dana Alokasi Khusus, dan Dana Bagi Hasil sebagai variabel independen. Variabel dependen menggunakan data variabel Belanja Modal pada laporan realisasi Anggaran Pendapatan dan Belanja Daerah (APBD). Jenis data yang digunakan dalam penelitian ini adalah data sekunder. Data sekunder merupakan data yang sudah tersedia dan dikumpulkan oleh pihak-pihak lain. Data yang diambil penelitian ini berasal dari Laporan Hasil Pemeriksaan Badan Pemeriksaan Keuangan tahun 2015-2017 dan data pertumbuhan ekonomi diambil dari situs Badan Pusat Statistik berupa Laporan PDRB atas Harga Konstan Pemerintah Kabupaten \& Pemerintah Kota di Provinsi Aceh tahun 2015-2017. Data tersebut akan digunakan untuk mendukung variabel-variabel yang digunakan dalam penelitian ini. Teknik pengambilan sampel yang digunakan adalah non probability sampling dengan teknik sampling jenuh.

Pengumpulan data dalam peneltian ini menggunakan metode dokumentasi dengan cara mengumpulkan seluruh data sekunder dan seluruh informasi yang digunakan untuk menyelesaikan masalah-masalah yang ada dalam penelitian ini. Pengambilan data Laporan Hasil Pemeriksaan Badan Pemeriksaan Keuangan melalui proses pengajuan data secara online pada website BPK RI www.bpk.go.id dan data PDRB pada website Badan Pusat Statistik (BPS) yaitu www.bps.go.id. Teknik analisis data yang digunakan adalah uji asumsi klasik, analisis regresi linier berganda, koefisien determinasi, uji F, dan uji t dengan bantuan Program SPSS.

\section{HASIL DAN PEMBAHASAN}

Data Penelitian

Dalam penelitian ini, populasi yang digunakan adalah semua kabupaten/kota di Provinsi Aceh, berjumlah 23 yang terdiri dari 18 kabupaten, dan 5 kota, dengan periode tahun 2015-2017. Sesuai dengan teknik sampling yang telah ditentukan, yaitu non probability sampling dengan teknik sampling jenuh, maka sampel dari penelitian ini yaitu semua kabupaten/kota di Provinsi Aceh, berjumlah 23 yang terdiri dari 18 kabupaten, dan 5 kota, dengan periode tahun 2015-2017. Ringkasan perolehan sampel penelitian disajikan pada table 2 .

Tabel 2 Perolehan sampel penelitian

\begin{tabular}{ll}
\hline Keterangan & Jumlah \\
\hline Kabupaten di Provinsi Aceh & 18 \\
Kota di Provinsi Aceh & 5 \\
Sampel & 23 \\
Observasi & $(18+5) \times 3=69$ observasi \\
\hline
\end{tabular}

Sumber: data sekunder yang diolah, 2019

Analisis Statistik Deskriptif

Tabel 3 Hasil Pengujian Statistik Deskriptif (Miliaran Rupiah)

\begin{tabular}{|c|c|c|c|c|c|}
\hline \multicolumn{6}{|c|}{ Descriptive Statistics } \\
\hline & $\mathrm{N}$ & Minimum & Maximum & Mean & Std. Deviation \\
\hline $\mathrm{PE}$ & 69 &,- 20 & ,13 & ,0339 &, 04004 \\
\hline PAD & 69 & 36 & 388 & 109,77 & 71,800 \\
\hline DAU & 69 & 292 & 844 & 542,15 & 147,037 \\
\hline DAK & 69 & 43 & 383 & 178,75 & 75,891 \\
\hline DBH & 69 & 12 & 359 & 35,70 & 52,257 \\
\hline BM & 69 & 129 & 512 & 302,40 & 77,137 \\
\hline Valid N (listwise) & 69 & & & & \\
\hline
\end{tabular}

Sumber: Hasil Olah Data SPSS 20.0

Analisis statistik deskriptif dalam penelitian ini meliputi rata-rata (mean), standar deviasi, nilai maksimal, nilai minimum dan jumlah data penelitian. Berikut ini hasil analisis statistik deskriptif data pada masing-masing variabel. 


\section{Uji Asumsi Klasik}

Sebelum dilakukan pengujian terhadap persamaan regresi, terlebih dahulu akan dilakukan pengujian terhadap gangguan-gangguan asumsi klasik. Uji yang dilakukan antara lain uji normalitas, uji multikolonieritas, uji autokorelasi, dan uji heteroskedastisitas.

Normalitas

Uji Normalitas bertujuan untuk menguji apakah dalam model regresi, variabel pengganggu atau residual memiliki distribusi normal (Ghozali,2016). Uji normalitas yang digunakan dalam penelitian ini adalah uji statistik non-parametrik Kolmogorov-Smirnov (K-S). Untuk mendeteksi normalitas data dapat juga dilakukan dengan uji One-Sample Kolmogorov Smirnov-Z. Residual berdistribusi normal jika nilai probabilitas (p) uji One-Sample Kolmogorov Smirnov-Z > 0,05 dan sebaliknya jika nilai probabilitas (p) uji One-Sample Kolmogorov Smirnov-Z < 0,05 maka residual tidak berdistribusi secara normal (Ghozali, 2016). Berikut ini hasil uji normalitas pada masingmasing variable.

Tabel 4 Hasil Uji Normalitas (Kolmogorov-Smirnov Test)

\begin{tabular}{lll}
\hline \multicolumn{2}{l}{ One-Sample Kolmogorov-Smirnov Test } & Unstandardized Residual \\
\hline $\mathrm{N}$ & & 69 \\
Normal Parameters & & $0 \mathrm{E}-7$ \\
& Mean & 49,96919351 \\
& Std. Deviation &, 076 \\
Most Extreme Differences & Absolute &, 076 \\
& Positive &,- 043 \\
Kolmogorov-Smirnov Z & Negative &, 635 \\
Asymp. Sig. (2-tailed) & &, 814 \\
a. Test distribution is Normal. & & \\
b. Calculated from data. & & \\
\hline
\end{tabular}

Sumber: Hasil Olah Data SPSS 20.0

Uji Multikolinearitas

Uji multikolonieritas bertujuan untuk menguji apakah model regresi ditemukan adanya korelasi antar variabel bebas (independen). Model regresi yang baik seharusnya tidak terjadi korelasi diantara variabel independen Multikolinearitas dapat dilihat dari perhitungan nilai tolerance dan Varian Inflation Factor (VIF). Apabila model regresi multikolinieritas jika nilai tolerance > 0,10 dan VIF > 10 maka tidak terjadi gejala multikolinearitas (Ghozali, 2016). Berikut ini hasil uji multikolinearitas pada masing-masing variable.

Tabel 5 Hasil Uji Multikolinearitas

\begin{tabular}{llllllll}
\hline Coefficients $^{2}$ & \multicolumn{2}{l}{$\begin{array}{l}\text { Unstandardized } \\
\text { Model }\end{array}$} & \multicolumn{2}{l}{$\begin{array}{l}\text { Standardized } \\
\text { Coefficients }\end{array}$} & & & \multicolumn{2}{l}{ Collinearity Statistics } \\
& $\mathrm{B}$ & Std. Error & Beta & $\mathrm{t}$ & Sig. & \multicolumn{2}{l}{$\begin{array}{l}\text { Tolerance } \\
\text { VIF }\end{array}$} \\
\hline (Constant) & 105,140 & 30,182 & & 3,484 &, 001 & & \\
PE & 68,113 & 197,229 &, 035 &, 345 &, 731 &, 635 & 1,574 \\
PAD &,- 226 &, 150 &,- 211 & $-1,510$ &, 136 &, 342 & 2,926 \\
DAU &, 192 &, 080 &, 365 & 2,405 &, 019 &, 289 & 3,461 \\
DAK &, 596 &, 099 &, 587 & 6,009 &, 000 &, 699 & 1,431 \\
DBH &, 262 &, 159 &, 177 & 1,647 &, 104 &, 574 & 1,742 \\
a. Dependent Variable: BM & & & & & & & \\
\hline
\end{tabular}

Sumber: Hasil Olah Data SPSS 20.0 
Uji Heterokedastisitas

Uji Heterokedastisitas bertujuan untuk menguji apakah dalam model regresi terjadi ketidaksamaan variance dari residual satu pengamatan ke pengamatan yang lain. Cara mendeteksi heteroskedastisitas adalah dengan uji Glejser, yakni dengan melihat probabilitas uji t. Jika nilai probabilitas uji $\mathrm{t}<0,05$ terhadap nilai absolute residualnya, maka dikatakan terjadi heteroskedastisitas, dan jika nilai probabilitas uji t $>0,05$ terhadap nilai absolute residualnya, maka dikatakan tidak terjadi heteroskedastisitas (Ghozali, 2016). Berikut ini hasil uji Heterokedastisitas pada masing-masing variable.

Tabel 6 Hasil Uji Heterokedastisitas (Glejser)

\begin{tabular}{|c|c|c|c|c|c|}
\hline \multirow[t]{2}{*}{$\begin{array}{l}\text { Coefficients }^{\mathrm{a}} \\
\text { Model }\end{array}$} & \multicolumn{2}{|c|}{ Unstandardized Coefficients } & \multirow{2}{*}{$\begin{array}{l}\text { Standardized } \\
\text { Coefficients } \\
\text { Beta }\end{array}$} & \multirow[t]{2}{*}{$\mathrm{T}$} & \multirow[t]{2}{*}{ Sig. } \\
\hline & $\mathrm{B}$ & Std. Error & & & \\
\hline (Constant) & 39,500 & 18,586 & & 2,125 & ,037 \\
\hline $\mathrm{PE}$ & 151,644 & 121,453 & , 192 & 1,249 & ,216 \\
\hline PAD &,- 111 & ,092 &,- 251 & $-1,201$ & ,234 \\
\hline $\mathrm{DAU}$ & ,021 & ,049 & ,095 & 418 & 677 \\
\hline DAK &,- 041 & 061 &,- 099 &,- 678 &, 501 \\
\hline DBH &, 061 & ,098 &, 101 & 623 &, 536 \\
\hline \multicolumn{6}{|c|}{ a. Dependent Variable: Abs_Res } \\
\hline
\end{tabular}

\section{Sumber: Hasil Olah Data SPSS 20.0}

Uji Autokorelasi

Uji autokorelasi bertujuan untuk menguji apakah dalam model regresi linear ada korelasi antara kesalahan pengganggu pada periode $t$ dengan kesalahan pengganggu pada periode $t-1$ (sebelumnya). Apabila nilai Durbin-Watson berada diantara nilai batas atas (Du) dan (4-Du) maka dapat dikatakan bahwa tidak ada gejala autokorelasi (Ghozali, 2016). Berikut hasil uji autokorelasi menggunakan pengujian Durbin-Watson (DW Test).

Tabel 7 Hasil Uji Autokorelasi (Durbin-Watson)

\begin{tabular}{lllll}
$\begin{array}{l}\text { Model Summary } \\
\text { Model R }\end{array}$ & R Square & Adjusted R Square & $\begin{array}{l}\text { Std. Error of the } \\
\text { Estimate }\end{array}$ & Durbin-Watson \\
\hline $1 \quad, 762^{\mathrm{a}}$ &, 580 & 51,914 & 1,603 \\
$\begin{array}{l}\text { a. Predictors: (Constant), DBH , DAK , PAD , PE , DAU } \\
\text { b. Dependent Variable: BM }\end{array}$ & & \\
\hline
\end{tabular}

Sumber: Hasil Olah Data SPSS 20.0

Tabel 8 Hasil Uji Autokorelasi (Cochrane-Orcutt)

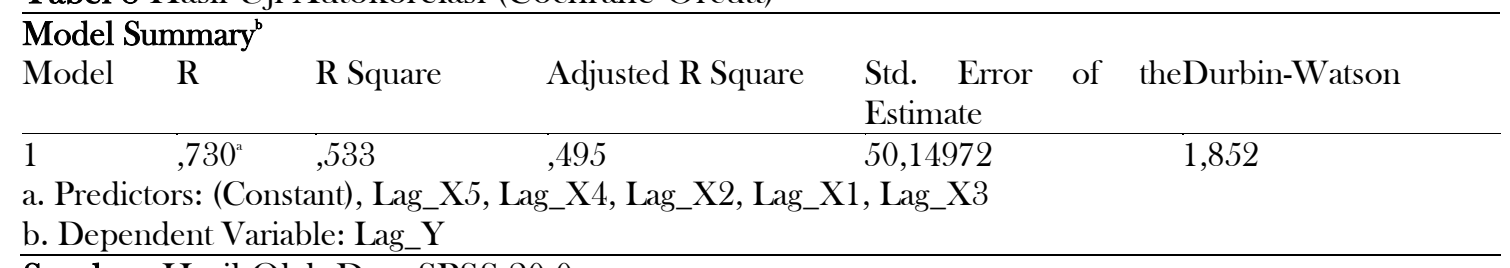

Sumber: Hasil Olah Data SPSS 20.0

Analisis Regresi Linear Berganda

Metode analisis yang digunakan adalah model regresi linier berganda. Analisis regresi linier berganda bermaksud meramalkan bagaimana keadaan (naik turunnya) variabel dependen, bila dua atau lebih variabel independen sebagai faktor prediator dimanipulasi (dinaik turunkan nilainya). 
Jadi analisis regresi berganda akan dilakukan bila jumlah variabel independennya minimal 2 (Sugiyono, 2014). Hasil uji regresi linear berganda dapat ditunjukan pada tabel berikut ini.

Tabel 9 Hasil Analisis Regresi Linear Berganda

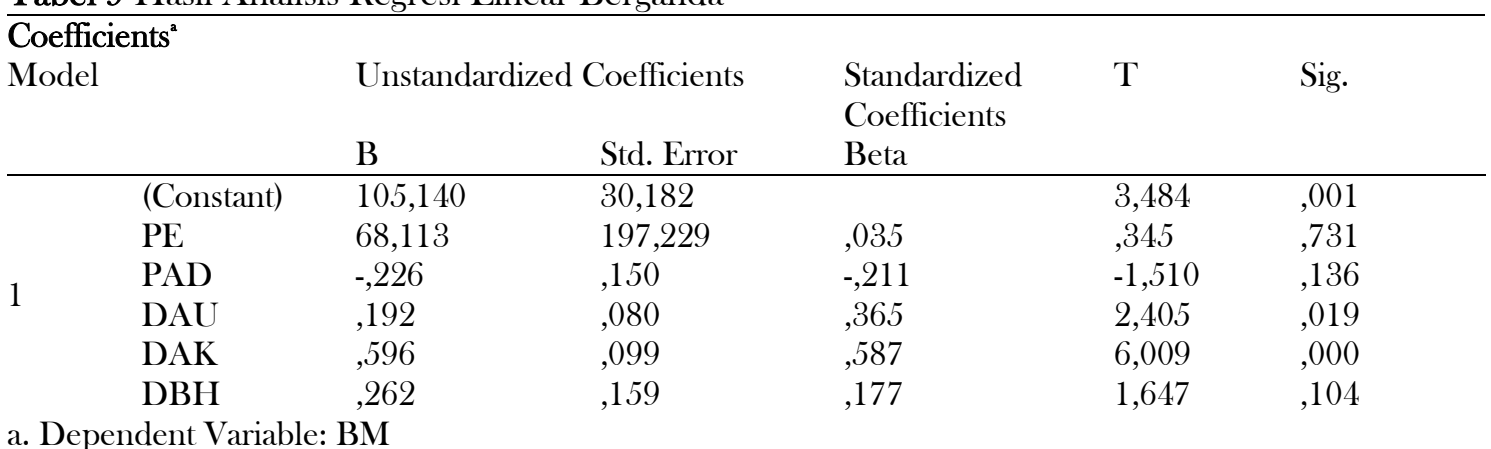

Sumber: Hasil Olah Data SPSS 20.0

Uji Koefisien Determinasi

Hasil uji koefisien determinasi $\left(\mathbf{R}^{2}\right)$ diatas besarnya Adjusted R Square adalah 0,547. Hal ini berarti 54,7\% variabel dependen BM dapat dijelaskan oleh variabel independen PE, PED, DAU, DAK, dan DBH. Sedangkan sisanya $(100 \%-54,7 \%=45,3 \%)$ dijelaskan oleh faktor-faktor lain di luar model yang diteliti. Hasil uji koefisien determinasi $\left(\mathbf{R}^{2}\right)$ dapat dilihat pada tabel berikut ini.

Tabel 10 Hasil Uji Koefisien Determinasi ( $\left.\mathrm{R}^{2}\right)$

\begin{tabular}{lllll}
\hline \multicolumn{2}{l}{$\begin{array}{l}\text { Model Summary } \\
\text { Model }\end{array} \quad \mathrm{R}$} & R Square & Adjusted R Square & Std. Error of the Estimate \\
\hline 1 &, $762^{n}$ &, 580 &, 547 & 51,914 \\
a. Predictors: (Constant), DBH , DAK , PAD , PE , DAU &
\end{tabular}

Sumber: Hasil Olah Data SPSS 20.0

Uji F

Uji $\mathrm{F}$ digunakan untuk mengetahui apakah variabel bebas (independen) secara bersamasama berpengaruh terhadap variabel terikat (dependen) (Ghozali, 2016). Berikut ini hasil uji F dapat dilihat pada tabel berikut ini.

Tabel 11 Hasil Uji Statistik F

\begin{tabular}{|c|c|c|c|c|c|c|}
\hline \multicolumn{7}{|c|}{ ANOVA $^{2}$} \\
\hline & Regression & 234814,750 & 5 & 46962,950 & 17,425 &, $000^{b}$ \\
\hline \multirow[t]{2}{*}{1} & Residual & 169790,580 & 63 & 2695,089 & & \\
\hline & Total & 404605,330 & 68 & & & \\
\hline \multicolumn{7}{|c|}{ a. Dependent Variable: BM } \\
\hline b. Predict & tors: (Const: & $\mathrm{DBH}, \mathrm{DAK}, \mathrm{PA}$ & PE & & & \\
\hline
\end{tabular}

\section{Sumber: Hasil Olah Data SPSS 20.0}

Berdasarkan hasil uji pada tabel diatas menunjukan bahwa nilai signifikansi sebesar 0,000 atau dengan kata lain lebih kecil nilai probabilitas (p-value) sebesar 0,05. Berdasarkan hasil uji $\mathbf{F}$ tersebut, maka dapat dikatakan bahwa model persamaan regresi yang digunakan dalam penelitian ini dalam kondisi layak untuk diinterpretsasikan. 
Uji Parsial (Uji t)

Uji t digunakan untuk menunjukkan seberapa jauh pengaruh satu variabel independen secara parsial atau individual dalam menerangkan variabel dependen. Pengujian dilakukan dengan menggunakan signifikansi level 0,05 ( $\alpha=5 \%)$ (Ghozali, 2016). Berikut ini hasil uji t dapat dilihat pada tabel berikut ini.

Tabel 12 Hasil Uji Parsial (Uji t)

\begin{tabular}{|c|c|c|c|c|c|}
\hline \multirow[t]{2}{*}{$\begin{array}{l}\text { Coefficients } \\
\text { Model }\end{array}$} & \multicolumn{2}{|c|}{ Unstandardized Coefficients } & \multirow{2}{*}{$\begin{array}{l}\text { Standardized } \\
\text { Coefficients } \\
\text { Beta }\end{array}$} & \multirow[t]{2}{*}{$\mathrm{t}$} & \multirow[t]{2}{*}{ Sig. } \\
\hline & $\mathrm{B}$ & Std. Error & & & \\
\hline (Constant) & 105,140 & 30,182 & & 3,484 & ,001 \\
\hline $\mathrm{PE}$ & 68,113 & 197,229 & ,035 & ,345 & ,731 \\
\hline PAD &,- 226 &, 150 &,- 211 & $-1,510$ & 136 \\
\hline $\mathrm{DAU}$ &, 192 & , 080 & ,365 & 2,405 & ,019 \\
\hline DAK &, 596 & ,099 &, 587 & 6,009 &, 000 \\
\hline $\mathrm{DBH}$ & ,262 & 159 &, 177 & 1,647 & 104 \\
\hline
\end{tabular}

\section{Sumber: Hasil Olah Data SPSS 20.0}

Hasil uji t menunjukan bahwa variabel (X1) tidak berpengaruh terhadap BM. Hal ini ditunjukan dari nilai signifikasi PE sebesar 0,731 yang lebih besar dari $\alpha=0,05(0,731>0,05)$. Dengan demikian H1 yang menyatakan Pertumbuhan Ekonomi berpengaruh terhadap Belanja Modal ditolak. Hasil penelitian ini sejalan dengan hasil penelitian Purwanto (2015), yang menunjukan bahwa Pertumbuhan Ekonomi tidak berpengaruh terhadap Belanja Modal. Hasil penelitian ini juga mendukung penelitian Dewi dan Suyanto (2015) yang menyatakan Pertumbuhan Ekonomi tidak berpengaruh terhadap Belanja Modal. Penelitian Rangkuti (2018) juga menunjukkan hasil yang sama dengan penelitian ini, yaitu Pertumbuhan Ekonomi berpengaruh negatif terhadap Belanja Modal. Hal ini disebabkan karena pemerintah daerah lebih banyak menggunakan belanja daerahnya untuk belanja rutin yang relatif kurang produktif serta pertumbuhan perekonomian kabupaten/kota diprovinsi Aceh rata-rata hanya sebesar 1\% sedangkan pertumbuhan ekonomi pada kabupaten dan kota di provinsi Aceh pada tahun 20152017 terus menunjukan tren positif dan pertumbuhan ekonomi tertinggi diraih pada tahun 2017 sebesar 4,61\% akan tetapi pertumbuhan tersebut masih dibawah target pertumbuhan ekonomi nasional yang mencapai lebih dari $5 \%$. Hal tersebut yang menyebabkan pemerintah daerah aceh memilah-milah dalam mengalokasikan belanja daerahnya dikarenakan dampak dari pertumbuhan tersebut adalah tidak berpengaruh secara besar terhadap pendapatan daerah khususnya pendapatan asli daerah yang didapat dari hasil pengelolaan sumber daya daerah sehingga pemerintah daerah memiliki sumber pendapatan yang terbatas.

Hasil uji t menunjukan bahwa variabel (X2) tidak berpengaruh terhadap BM. Hal ini ditunjukan dari nilai signifikasi PAD sebesar 0,136 yang lebih besar dari $\alpha=0,05(0,136>0,05)$. Dengan demikian H1 yang menyatakan Pendapatan Asli Daerah berpengaruh terhadap Belanja Modal ditolak. Hasil penelitian ini sejalan dengan hasil penelitian Pradita (2013), yang menunjukan bahwa Pendapatan Asli Daerah tidak berpengaruh terhadap Belanja Modal. Hasil penelitian ini juga mendukung penelitian Huda (2018) yang menyatakan Pertumbuhan Ekonomi tidak berpengaruh terhadap Belanja Modal. Penelitian Suryani dan Pariani (2018) juga menunjukkan hasil yang sama dengan penelitian ini, yaitu Pendapatan Asli Daerah berpengaruh negatif terhadap Belanja Modal. Ada beberapa faktor yang menyebabkan Pendapatan Asli Daerah tidak berpengaruh terhadap belanja modal. Faktor pertama disebabkan karena kecilnya kontribusi penerimaan pemerintah daerah terhadap total pendapatan yang didapat oleh pemerintah daerah yaitu pada tahun 2015 tercatat sebesar 8,3\% serta pada tahun 2016 dan 2017 tercatat sebesar 8,4\% dan 8,6\%. Hal tersebut dapat disebabkan kurang terkelolanya sumber-sumber penerimaan daerah atau pemerintah daerah masih belum mampu untuk menggalinya. Faktor kedua pada penelitian ini 
mengindikasikan bahwa besarnya PAD tidak menjadi salah satu faktor penentu dalam menentukan belanja modal. Hal tersebut dapat dilihat dari hasil analisis Laporan Keuangan Pemerintah Daerah pada Kabupaten/Kota di Provinsi Aceh tahun 2015-2017 menunjukan bahwa kota Banda Aceh mempunyai tingkat prosentase pendapatan asli daerah tertinggi dibandingkan dengan kabupaten/kota lain di wilayah Provinsi Aceh yaitu prosentase pada tahun 2015 sebesar 17,2\%, pada tahun 2016 dan 2017 mencapai sebesar 19,6\% dan 21,7\% realisasi pada kota Banda Aceh selama tiga tahun mengalami peningkatan akan tetapi hasil realisasi belanja modal pada kota banda aceh memiliki prosentase terkecil dibandingkan dengan kabupaten/kota lain di wilayah Provinsi Aceh hanya mencapai 19\% pada tahun 2015, dan pada tahun 2016 dan 2017 mencapai tingkat prosentase yang sama yaitu sebesar $21 \%$. Faktor ketiga penyebab PAD tidak berpengaruh terhadap belanja modal adalah dikarenakan Pemerintah Daerah memiliki rencana pembangunan masing-masing tergantung pada pola-pola kebijakan, prioritas penggunaan anggaran, dan program-program untuk setiap tahunnya. Hal tersebut dapat dilihat dari LRA kabupan/kota pada provinsi aceh yang banyak menggunakan anggarannya untuk belanja pegawai dan belanja langsung lainnya.

Hasil uji t menunjukan bahwa variabel (X3) berpengaruh terhadap BM. Hal ini ditunjukan dari nilai signifikasi DAU sebesar 0.019 yang lebih kecil dari $\alpha=0,05(0.019>0,05)$. Dengan demikian H1 yang menyatakan Dana Alokasi Umum berpengaruh terhadap Belanja Modal diterima. Hasil penelitian ini sejalan dengan hasil penelitian Eksandy, Hakim, dan Ekawati (2018), yang menunjukan bahwa Dana Alokasi Umum berpengaruh terhadap Belanja Modal. Hasil penelitian ini juga mendukung penelitian Mubasiroh (2018) yang menyatakan Dana Alokasi Umum berpengaruh terhadap Belanja Modal. Penelitian Sulistyorini (2018) juga menunjukkan hasil yang sama dengan penelitian ini, yaitu Dana Alokasi Umum berpengaruh positif terhadap Belanja Modal. Kabupaten/Kota pada Provinsi Aceh merupakan daerah yang mempunyai ketergantungan yang cukup tinggi pada struktur pendapatannya dimana kontribusi Dana Alokasi Umum terhadap total pendapatan daerah yaitu sebesar $45 \%$ dibandingkan dengan PAD hanya berkontribusi sebesar 8\% serta DAK dan DBH berkontribusi sebesar 15\% dan 3\%. Dari hasil analisa diatas dapat disimpulkan bahwa Dana Alokasi Umum merupakan salah satu sumber pendanaan yang memiliki kontribusi yang cukup signifikan terhadap pendapatan daerah sehingga pemerintah daerah dapat menggunakannya untuk memberi pelayanan publik yang lebih baik atau pelayanan lain.

Hasil uji t menunjukan bahwa variabel (X4) berpengaruh terhadap BM. Hal ini ditunjukan dari nilai signifikasi DAK sebesar 0,000 yang lebih kecil dari $\alpha=0,05(0,000>0,05)$. Dengan demikian H1 yang menyatakan Dana Alokasi Khusus berpengaruh terhadap Belanja Modal diterima. Hasil penelitian ini sejalan dengan hasil penelitian Gerungan dkk.(2017), yang menunjukan bahwa Dana Alokasi Khusus berpengaruh terhadap Belanja Modal. Hasil penelitian ini juga mendukung penelitian Fadillah (2017) yang menyatakan Dana Alokasi Umum berpengaruh terhadap Belanja Modal. Penelitian Karyadi (2017) juga menunjukkan hasil yang sama dengan penelitian ini, yaitu Dana Alokasi Umum berpengaruh positif terhadap Belanja Modal. Dana Alokasi Khusus adalah dana yang bersumber dari pendapatan APBN yang dialokasikan kepada daerah tertentu dengan tujuan untuk membantu mendanai kegiatan khusus yang merupakan urusan daerah dan sesuai dengan prioritas nasional. Pemanfaatan Dana Alokasi Khusus diarahkan pada kegiatan investasi pembangunan, pengadaan, peningkatan dan perbaikan sarana dan prasarana fisik dengan umur ekonomis yang panjang, termasuk pengadaan sarana fisik penunjang. Dengan adanya pengalokasian Dana Alokasi Khusus diharapkan dapat mempengaruhi pengalokasian anggaran Belanja Modal karena Dana Alokasi Khusus cenderung akan menambah asset tetap yang dimiliki oleh pemerintah guna meningkatkan pelayanan publik.

Hasil uji t menunjukan bahwa variabel (X5) berpengaruh terhadap BM. Hal ini ditunjukan dari nilai signifikasi DBH sebesar 0,104 yang lebih besar dari $\alpha=0,05(0,104>0,05)$. Dengan demikian H1 yang menyatakan Dana Alokasi Khusus berpengaruh terhadap Belanja Modal ditolak. Hasil penelitian ini sejalan dengan hasil penelitian Nughroho (2018), yang menunjukan bahwa Dana Bagi Hasil tidak berpengaruh terhadap Belanja Modal. Dana Bagi Hasil pada Kabupaten/Kota di Provinsi Aceh memiliki kontribusi yang kecil dibandingkan dengan sumber pendanaan yang lain yaitu pada tahun 2015 hanya berkontribusi sebesar 3,3\% sedangkan pada 
tahun 2016 dan 2017 hanya berkontribusi sebesar 2,2\% dan 2,5\%. Hal tersebut yang menyebabkan Dana Bagi Hasil tidak berpengaruh terhadap belanja modal.

\section{KESIMPULAN}

Berdasarkan penelitian pada Pemerintah Kabupaten dan Kota di Provinsi Aceh selama tahun 2015-2017, dapat disimpulkan bahwa Pertumbuhan Ekonomi, Pendapatan Asli Daerah, Dana Bagi Hasil tidak berpengaruh terhadap belanja modal dan variabel Dana Alokasi Umum, Dana Alokasi Khusus berpengaruh terhadap belanja modal.

Berdasarkan kesimpulan yang dihasilkan dalam penelitian ini, maka penulis menyampaikan beberapa saran yang diharapkan dapat berguna untuk penelitian selanjutnya atau pihak yang menjadi objek penelitian, diantaranya penelitian selanjutnya tidak hanya menggunakan data sekunder dari laporan realisasi APBD, tetapi juga melalui metode observasi secara langsung dengan menggunakan teknik pengambilan data wawancara atau kuisioner. Bagi Pemerintah daerah agar dapat berusaha untuk mengoptimalkan tingkat pendapatan asli daerah misalnya dengan membentuk peraturan daerah tentang pajak dan retribusi daerah secara jelas dan tegas ataupun dengan memberikan kesempatan bagi putra-putra daerah untuk mengelola/bekerjasama dengan pihak -pihak yang mampu mengelola sumber daya yang dimiliki daerah, sehingga sumber-sumber pendapatan daerah mampu dimanfaatkan sebaik mungkin dan hal ini berarti bahwa pendapatan asli daerah akan semakin meningkat dan tingkat ketergantungan terhadap transfer dari pusat juga semakin berkurang sehingga otonomi daerah dapat berjalan dengan baik. Selanjutnya bagi pemerintah daerah kabupaten dan kota di Provinsi Aceh, dapat memanfaatkan sumber pendapatan yang dimilikinya untuk dialokasikan kepada Belanja Modal yang secara tidak langsung dapat meningkatkan Pendapatan Asli Daerah.

\section{DAFTAR PUSTAKA}

Aditya, D. M E., \& Maryono. (2018). Pengaruh Pendapatan Asli Daerah, Dana Alokasi Umum, Dana Alokasi Khusus, Dana Bagi Hasil Terhadap Belanja Modal Studi Pada Provinsi/Wilayah Kalimantan dan Sulawesi. Prosiding Sendi_U, ISBN: 978-979-364999-3.

Aditya, N. Y., \& Dirgantari, N. (2017). Pengaruh Pendapatan Asli Daerah, Dana Alokasi Umum, Dana Alokasi Khusus, Dan Sisa Lebih Pembiayaan Anggaran Terhadap Belanja Modal Pada Kabupaten Dan Kota Di Jawa Tengah Tahun 2013- 2015. Kompartemen, XV(1).

Ardhini. (2011). Pengaruh Rasio Keuangan Daerah Terhadap Belanja Modal Untuk Pelayanan

Publik Dalam Prespektif Teori Keagenan (Studi Pada Kabupaten dan Kota Di Jawa Tengah). Skripsi, Universitas Dipenegoro.

Ayem, S. \& Pratama, D. D. (2018). Pengaruh Pertumbuhan Ekonomi, Dana Alokasi

Umum,Dana Alokasi Khusus Dan Pendapatan Asli Daerah Terhadap Belanja Modal. Jurnal Akuntansi, ISSN: 2549-9637.

Dewi, S. P., \& Suyanto. (2015). Pengaruh Pertumbuhan Ekonomi, Pendapatan Asli Daerah, Dana Alokasi Umum, Dana Alokasi Khusus Terhadap Belanja Modal Pada Provinsi Jawa Tengah. Jurnal Akuntansi, 3 (1).

Eksandy, Arry, Hakim, Zulman, M., \& Ekawati. (2018). Pengaruh Pendapatan Asli Daerah, Dana Alokasi Umum Dan Dana Alokasi Khusus Terhadap Belanja Modal (Pada Pemerintah Provinsi Banten Periode 2011-2015). Jurnal Akuntansi Keuangan, 2 (2), 85-94.

Erlina. (2011). Metodologi Penelitian, USU Press.

Fadillah, R. (2017). Pengaruh Pendapatan Asli Daerah, Dana Alokasi Umum, Dana Alokasi Khusus, dan Dana Bagi Hasil Terhadap Belanja Modal. Jurnal Online Mahasiswa, 4 (2). 
Faith, V. (2018). Pengaruh Dana Alokasi Umum, Dana Alokasi Khusus, Pendapatan Asli Daerah, Sisa Lebih Pembiayaan Anggaran,dan Luas Wilayah Terhadap Belanja Modal Pada Kabupaten dan Kota di Jawa Timur. Skripsi, Universitas Muhammadiyah Surakarta.

Gerungan, Henri, Saerang, David P.E \& Ilat, Ventje. (2017). Pengaruh Pendapatan Asli Daerah, Dana Alokasi Umum, Dan Dana Alokasi Khusus Terhadap Belanja Modal (Studi Kasus Pada Pemerintah Daerah Kabupaten Dan Kota Di Provinsi Sulawesi Utara). Jurnal Riset Akuntansi dan Auditing, 8 (1).

Ghozali, I. (2016). Aplikasi Analisis Multivariate dengan program SPSS. Semarang: Badan penerbit Universitas Diponegoro

Ginting, R. (2017). Pengaruh Dana Alokasi Umum, Pendapatan Asli Daerah, Sisa Lebih Pembiayaan Anggaran, Dan Luas Wilayah Terhadap Belanja Modal. Jurnal Online Mahasiswa, 4 (2).

Ginting, R. (2017). Pengaruh Dana Alokasi Umum, Pendapatan Asli Daerah, Sisa Lebih Pembiayaan Anggaran dan Luas Wilayah Terhadap Belanja Modal. Jurnal Online Mahasiswa 4 (2).

Gujarati, D. (2003). Ekonomika Dasar, Alih Bahasa Sumarno Zain. Jakarta: Erlangga Halim, A. (2004). Akuntansi Keuangan Daerah. Edisi Revisi. Jakarta: Salemba Empat. Huda, M. (2018). Pengaruh Dana Alokasi Umum (Dau), Dana Alokasi Khusus (Dak), Pendapatan Asli Daerah (Pad) Dan Produk Domestik Regional Bruto (Pdrb) Terhadap Belanja Modal Pemerintah Daerah Di Provinsi Jawa Tengah Periode 2015-2017. Skripsi, Institut Agama Islam Negeri Surakarta.

Jesen \& Meckling. (1976), The Theory of The Firm: Manajerial Behaviour, Agency Cost, and Ownership Structure. Journal of Financial and Economics, 3:305-360.

Jolianis. (2016). Analisis Pengaruh PAD, DAU dan DAK Terhadap Kemiskinan Pada Kabupaten/Kota Di Provinsi Sumatera Barat Dengan Pertumbuhan Ekonomi Sebagai Variabel Intervening. Journal of Economic and Economic Education, 4(2), 34-57.

Junaedy. (2015). Pengaruh Dana Alokasi Umum, Pendapatan Asli Daerah, Dana Bagi Hasil, Sisa Lebih Pembiayaan Anggaran Dan Luas Wilayah,Terhadap Belanja Modal. Jurnal Akuntansi dan Manajemen.

Karyadi, S. A. (2017). Pengaruh Pendapatan Asli Daerah, Dana Alokasi Umum, Dan Dana Alokasi Khusus Terhadap Belanja Modal Pada Kabupaten Dan Kota Di Provinsi Jawa Tengah Tahun 2011-2014. Skripsi, Universitas Negeri Yogyakarta.

Khasanah, M. (2016). Pengaruh Pendapatan Asli Daerah (Pad), Dana Alokasi Umum (Dau), Dana Alokasi Khusus (Dak) Terhadap Belanja Modal Di Kota/Kabupaten Se-Jawa Timur.Jurnal Riset Mahasiswa Akuntansi Unikma.

Kusnandar, \& Dodik Siswantoro. (2012). Pengaruh Dana Alokasi Umum, Pendapatan Asli Daerah, Sisa Lebih Pembiayaan Anggaran, dan Luas Wilayah Belanja Modal. Simposium Nasional Akuntansi XV, Banjarmasin, Hal. 1-16.

Lane, Jan-Erik. (2003). Management and public organization: The principal-agent framework. University of Geneva and National University of Singapore. Working paper.

Mardiasmo. (2002). Otonomi dan Manajemen Keuangan Daerah. Yogyakarta: Penerbit Andi.

Mubasiroh, L. (2018). Pengaruh Pendapatan Asli Daerah (Pad), Dana Alokasi Umum (Dau) Dan Dana Alokasi Khusus (Dak) Terhadap Belanja Modal Di Provinsi Daerah Istimewa Yogyakarta Tahun 2010-2016. Skripsi, Universitas Negeri Yogyakarta.

Nopitasari, E. D. (2017). Pengaruh Pendapatan Asli Daerah, Dana Alokasi Umum, Dan Produk Domestik Regional Bruto Terhadap Belanja Modal. Skripsi, Institut Agama Islam Negeri Surakarta.

Nughroho, A. (2018). Pengaruh Pendapatan Asli Daerah (PAD), Dana Alokasi Umum (DAU), Dana Alokasi Khusus (DAK) dan Dana Bagi Hasil (DBH) terhadap Belanja Modal. Skripsi, Universitas Mercu Buana.

Peraturan Direktur Jenderal Perbendaharaan PER-33/PB/2008 Tentang Pedoman Penggunaan Akun Pendapatan, Belanja Pegawai, dan Belanja Modal 
Peraturan Menteri Dalam Negeri No.59 Tahun 2007 Tentang Pedoman Pengelolaan Keuangan Daerah

Peraturan Menteri Keuangan No.214/PMK.05/2013 Tentang Bagan Akun Standar

Peraturan Pemerintah No.12 Tahun 2019 Tentang Pengelolaan Keuangan Daerah

Peraturan Pemerintah No.71 Tahun 2010 Tentang Standar Akuntansi Pemerintahan

Peraturan Pemerintah nomor 55 tahun 2005 Tentang Dana Perimbangan

Peraturan Presiden No.2 Tahun 2015 Tentang Rencana Pembangunan Jangka Menengah

Pohan, A. L. H. (2018). Pengaruh Pertumbuhan Ekonomi, Pendapatan Asli Daerah, Dana

Alokasi Umum, Dana Alokasi Khusus, dan Dana Bagi Hasil terhadap Pengalokasian

Anggaran Belanja Modal Kabupaten/Kota di Provinsi Nanggroe Aceh Darussalam.

Skripsi, Universitas Sumatra Utara.

Pradita, R. R. Pengaruh Pendapatan Asli Daerah dan Dana Alokasi Umum Terhadap Belanja

Modal Di Provinsi Jawa Timur. Jurnal Akuntansi Unesa, 1 (2).

Purwanto, D. (2015). Analisis Pengaruh Pertumbuhan Ekonomi, Pendapatan Asli Daerah, Dana Alokasi Umum, Produk Domestik Regional Bruto Terhadap Belanja Modal. Jurnal Akuntansi dan Sistem Teknologi Informasi, 11(2), 263-271.

Purwanto, F. P. D. (2013). Pengaruh Pertumbuhan Ekonomi, Pendapatan Asli Daerah, Dan

Dana Alokasi Umum Terhadap Belanja Modal. Skripsi, Universitas Negeri Yogyakarta.

Putro, N. S., \& Pamudji, S. (2011). Pengaruh pertumbuhan ekonomi, anggaran belanja Modal pendapatan asli daerah dan dana alokasi umum terhadap pengalokasian Belanja Modal. Jurnal Penelitian.

Rangkuti, M. T. (2018). Pengaruh Pertumbuhan Ekonomi, Pendapatan Asli Daerah, dan Dana Perimbangan Terhadap Belanja Modal pada Pemerintah Kabupaten/Kota di Provinsi Sumatra Utara Periode 2014-2016. Skripsi. Universitas Sumatra Utara, Medan.

Rohini, S. 2019. Pengaruh Luas Wilayah, Sisa Lebih Pembiayaan Anggaran, Dan Pertumbuhan Ekonomi Terhadap Belanja Modal. Skripsi. Institut Agama Islam Negeri Surakarta.

Situmorang, S. H., \& Lutfi, M. (2014). Analisis Data. USU Press.

Sudrajat, M. A., \& Purniawati, I. D. (2017). Analisis Pengaruh Pad, Dbh, Dau, Dak Dan Pertumbuhan Ekonomi Terhadap Belanja Modal Kabupaten Ngawi Tahun 2003-2015. Jurnal Akuntansi, 1 (1).

Sugiyanta. (2016). Analisis Belanja Modal Dan Faktor-Faktor Yang Mempengaruhinya Pada Pemerintah Kabupaten/Kota Di Indonesia. Jurnal Akuntansi, 14 (1).

Sugiyono. 2017. Metode Penelitian Kuantitatif Kualitatif dan R\&D. Bandung: Alfabeta.

Sukirno. S. (2006). Ekonomi Pembangunan, Penerbit: Kencana, Jakarta.

Sulistyorini, E. (2018). Pengaruh Pertumbuhan Ekonomi, Pendapatan Asli Daerah, Dan Dana Alokasi Umum Terhadap Belanja Modal Pada Kota/Kabupaten Di Provinsi Jawa Timur. Simki-Economic, 2 (2).

Suryani, F., \& Pariani, E. (2018). Pengaruh Pendapatan Asli Daerah Dan Dana Alokasi Umum Terhadap Belanja Modal Pada Kabupaten/Kota Di Provinsi Riau. Jurnal Pendidikan Ekonomi Akuntansi, 6 (1).

Susanti, S. 2016. Pengaruh Pendapatan Asli Daerah, Dana Alokasi Umum, Dan Dana Bagi Hasil Terhadap Belanja Modal (Studi pada Kabupaten/Kota di Wilayah Aceh). Skripsi. Universitas Syiah Kuala Darussalam-Banda Aceh.

Susanti, S., \& Fahlevi, H. (2016). Pengaruh Pendapatan Asli Daerah, Dana Alokasi Umum, Dan Dana Bagi Hasil Terhadap Belanja Modal (Studi Pada Kabupaten/Kota Di Wilayah Aceh). Jurnal Ilmiah Mahasiswa Ekonomi Akuntansi, 1 (1), 183-191.

Syaiful. (2006). Pengertian dan Pelakuan Akuntansi Belanja Barang dan Belanja Modal dalam Kaidah Akuntansi Pemerintahan. Makalah Ilmiah. STIE Yadika, Jawa Timur.

Syukriy, A dan Halim, A. (2006). Studi atas Belanja Modal pada Anggaran Pemerintah Daerah dalam Hubungannya dengan Belanja Pemerintahan dan Sumber Pendapatan. Jurnal Akuntansi Pemerintah, 2 (2), 17-32.

Undang-Undang No. 33 Tahun 2004 tentang Perimbangan Keuangan antara Pemerintah pusat dan Pemerintah daerah 
Undang-Undang No.17 Tahun 2003 Tentang Keuangan Negara

Undang-undang No.28 Tahun 2009 Tentang Pajak Daerah dan Retribusi Daerah

Undang-undang No.9 Tahun 2015 Tentang Pemerintah Daerah

Undang-Undang Nomor 11 Tahun 2006 tentang Pemerintahan Aceh

Undang-Undang Nomor 18 Tahun 2001 tentang Otonomi Khusus bagi Daerah Istimewa Aceh sebagai Provinsi Aceh

Wandira, A. G. (2013). Pengaruh PAD, DAU, DAK, Dan DBH Terhadap Pengalokasian Belanja Modal. Jurnal Analisis Akuntansi, 2 (1).

Yawa, H. \& Runtu, T. (2015). Pengaruh Dana Alokasi Umum (Dau) Dan Pendapatan Asli Daerah (Pad) Terhadap Belanja Modal Di Kota Manado. Jurnal Akuntansi, 15 (4). 